\title{
EKSPLOITASI SUMBER DAYA IKAN TERBANG (Hirundichthys oxycephalus, FAMILI EXOCOETIDAE) DI PERAIRAN PAPUA BARAT: PENDEKATAN RISET DAN PENGELOLAAN
}

\author{
Suwarso, Achmad Zamroni, dan Wijopriyono \\ Peneliti pada Balai Riset Perikanan Laut, Muara Baru-Jakarta \\ Teregristrasi I tanggal: 9 Oktober 2007; Diterima setelah perbaikan tanggal: 31 Maret 2008; \\ Disetujui terbit tanggal: 4 April 2008
}

\begin{abstract}
ABSTRAK
Studi tentang perikanan ikan terbang atau torani didasarkan pada data operasional, hasil tangkapan telur, registrasi kapal penangkap dan produk terkirim, serta hasil observasi lapangan di Kabupaten Fak-Fak dan sekitarnya. Jenis utama yang dieksploitasi adalah ikan terbang (bony flyingfish) (Hirundichthys oxycephalus, famili Exocoetidae), salah satu jenis utama yang juga dieksploitasi di Selat Makassar sampai Laut Flores. Perikanan tangkap kapal-kapal pakaja asal Selat Makassar yang mengupayakan telur ikan terbang ini mulai berkembang intensif sejak tahun 2002. Daerah penangkapan di perairan laut dalam (oseanik) di perairan barat Papua Barat, berbatasan dengan Laut Seram. Setiap tahun musim penangkapan telur ikan terbang berlangsung selama 5 bulan (bulan Mei-September) dengan puncaknya antara bulan Juli-Agustus, di mana waktu-waktu tersebut merupakan musim pemijahan. Sejalan dengan peningkatan produksi telur selama tahun 2001-2007, semakin banyak juga jumlah upayanya (jumlah kapal aktif). Hasil tangkapan per kapal bervariasi, tetapi fluktuasi hasil tangkapan telur rata-rata diduga sesuai dengan puncak musim pemijahan. Meski produksi telur selama tahun 2001-2007 menunjukkan peningkatan, tetapi hal ini belum menjamin pola eksploitasi yang bertanggungjawab sekaligus menjamin kelestarian sumber dayanya. Identifkasi beberapa permasalahan yang diisyaratkan terkait dengan pengelolaan perikanan juga diuraikan.
\end{abstract}

KATAKUNCl: eksploitasi, sumber daya ikan terbang atau torani, Exocoetidae, hasil tangkapan, upaya, Kabupaten Fak-Fak

\section{PENDAHULUAN}

Ikan terbang (Hirundichthys oxycephalus, famili Exocoetidae) termasuk ikan pelagis kecil yang memiliki nilai ekonomis penting, terutama telurnya sebagai komoditi ekspor ke Jepang, Korea, dan Taiwan (Peranginangin, 2006). Walaupun harga berfluktuasi, tetapi relatif tinggi. Tahun 1981-an komoditi telur ikan terbang menjadi penghasil devisa kedua setelah udang di Indonesia (Ali \& Nessa, 2006). Selama lebih dari 30 tahun, ekspor telur ikan terbang (Hirundichthys oxycephalus) terutama berasal dari Sulawesi Selatan sebagai salah satu sentra produksi terbesar. Ekspor telur ikan pertama tahun 1969 ke Jepang, sedangkan volume ekspor tertinggi sekitar 400 ton tercapai tahun 1983 (Kantor Wilayah Perdagangan, 1984 dalam Hutomo et al., 1985; Dinas Perikanan Sulawesi Selatan, 1984 dalam Hutomo et al., 1985). Namun, pada tahun-tahun terakhir kontribusinya sangat menurun, tahun 2000 volume ekspor hanya 93 ton, dan tahun 2003 hanya 194 ton.

Eksploitasi berlebih baik terhadap ikan maupun telurnya di Selat Makasar sampai Laut Flores rupanya telah mengakibatkan penurunan stok ikan terbang beserta hasil tangkapan telurnya sehingga dalam 7 tahun terakhir produksi telur dan ikan menurun tajam
(Syahailatua, 2006; Ali \& Nessa, 2006). Dalam kurun waktu tahun 1985-2002, penurunan produksi ikan ratarata sekitar 155 ton/tahun, sementara penurunan produksi telur rata-rata sekitar 5 ton/tahun. Lebih jauh, faktanya terjadi penurunan ukuran panjang rata-rata ikan terbang dibanding beberapa tahun sebelumnya (Ali dalam Ali \& Nessa, 2006) menunjukkan suatu indikasi terjadi lebih tangkap (recruitment overfishing), bahkan pada tahun 1993 jenis Cypselurus poecilopterus (Selat Makassar) ditetapkan sebagai biota langka kategori V (Anonimus, 1993). Artinya, jenis ini benar-benar telah mengalami kelangkaan, tapi belum dapat ditetapkan tingkat kelangkaan karena penilaian stok belum dilakukan sedang data atau informasi sebelumnya belum mencukupi.

Perburuan telur ikan terbang rupanya tidak berhenti. Sebelum usaha ke arah pengelolaan yang bertanggungjawab beserta pengembangannya, khususnya di Sulawesi Selatan (rencana ini tertuang pada Loka Karya Nasional Perikanan Ikan Terbang tahun 2005 di Ujung Pandang, sekaligus menyusun naskah akademik rencana pengelolaan perikanan ikan terbang, dapat terealisasi dan dilaksanakan secara optimal.Ekspansi ke daerah penangkapan baru dilakukan nelayan Selat Makassar (Galesong, Takalar) ke perairan sebelah barat Papua Barat sejak 
tahun 2002 untuk mengeksploitasi telur ikan terbang di daerah ini.

Dalam tulisan ini dibahas kondisi perikanan ikan terbang (Hirundichthys oxycephalus) yang berkembang di sekitar Fak-Fak (Papua Barat), mencakup armada, alat tangkap, daerah penangkapan, strategi penangkapan, trend produksi dan upayanya, serta keragaman hasil tangkapan telur. Hasilnya diharapkan dapat memberi informasi sebagai masukan dalam penentuan kebijakan pengelolaan yang bertanggungjawab dalam arti pengelolaan tersebut akan dapat menjamin penangkapan yang menguntungkan tetapi ketersediaan sumber daya tetap terjamin dalam jangka panjang (Martosubroto, 2005).

\section{JENIS IKAN TERBANG YANG DIEKSPLOITASI TELURNYA}

Ikan terbang dikenal dengan nama torani atau tuing-tuing, dan ditemukan hampir di semua perairan tropik dan sub tropik hidup di permukaan perairan pantai maupun lepas pantai yang bersifat oseanik. Di daerah tropis, ikan terbang melimpah sebagai sumber daya ikan yang dieksploitasi perikanan skala kecil (Parin, 1999). Di Indonesia, distribusi ikan terbang antara lain tersebar di Selat Makassar, Laut Flores, Laut Banda, Laut Sulawesi, Laut Maluku, Laut Arafura, Laut Utara Papua, Laut Halmahera, Laut Sawu, perairan selatan Bali dan Jawa Timur, pantai barat Sumatera, dan perairan Sabang sampai Banda Aceh (Hutomo et al., 1985; Ali \& Nessa, 2006).

Ada 18 spesies ikan terbang yang ditemukan di perairan Indonesia (Parin, 1999; Weber \& Beaufort, 2004). Hutomo et al. (1985) hanya mendeskripsikan 15 spesies. Di perairan Selat Makassar sampai Laut Flores ditemukan 10 spesies, di Laut Sulawesi sampai dengan Halmahera 2 spesies, dan di Maluku Tengah
5 spesies. Berdasarkan pada identifikasi jenis yang dilakukan pada awal bulan Agustus 2007, mengacu pada Parin (1999), diperoleh jenis ikan terbang yang dieksploitasi telur di perairan barat Papua antara lain Hirundichthys oxycepalus (Bleeker, 1852), famili Exocoetidae (Gambar 1). Spesies ini juga dikatakan merupakan jenis dominan di Selat Makassar sampai Laut Flores (Nessa et al., 1977; Ali, 1981) dan Maluku Tengah (Syahailatua et al., 2006). Di Philipina (sebelah barat pulau Luzon), jenis Hirundichthys oxycepalus termasuk paling dominan (Dalzell, 1993).

Contoh telur ikan terbang yang dipanen nelayan di perairan Fak-Fak (menempel pada rumpon atau daun kelapa) diperlihatkan pada Gambar 2a dan b. Butiran telur berwarna orange cerah atau merah orange, berserat (membran) berupa benang-benang putih yang elastis kuat. Pengamatan secara mikroskopis terhadap telur segar yang telah dipijahkan dan diawet larutan Gilson (perbesaran 40x) ini menunjukkan bahwa diameter telur (ova) berkisar antara 58-73 unit mikron, modus sekitar 70 unit mikron (Gambar 2c). Hasil pengukuran Ali (1981) terhadap telur ikan terbang di perairan Selat Makassar sampai dengan Laut Flores mengatakan diameter telur siap mijah (dalam gonad yang matang atau mature, terdapat di dalam tubuh ikan) berkisar antara 1,49 sampai $1,79 \mathrm{~mm}$.

\section{PERKEMBANGAN EKSPLOITASI DAN HASIL TANGKAPAN}

Perikanan ikan terbang di Kabupaten Fak-Fak (Papua Barat) mulai berkembang tahun 2002, dirintis oleh nelayan ikan terbang asal Selat Makassar (Galesong, Takalar). Pada awalnya, ikan terbang ditemukan secara tidak sengaja pada tahun 2001 , ketika pertama kali 2 kapal nelayan dari Selat Makassar (Galesong atau Takalar, milik H. Nyarang) datang ke daerah ini untuk menangkap hiu. Sewaktu

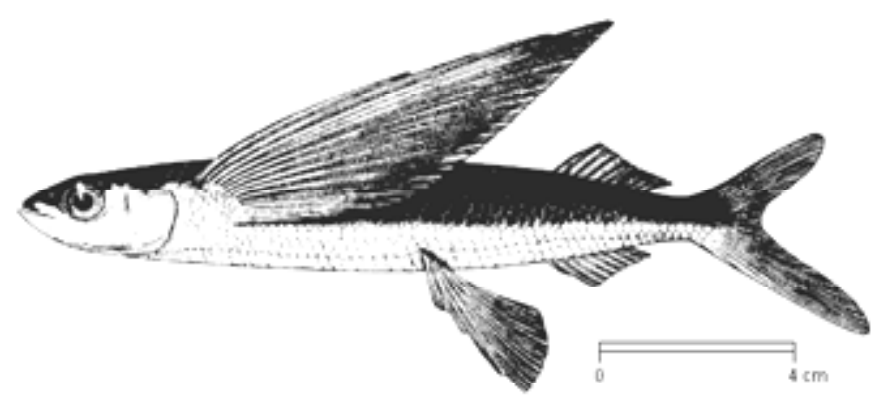

Gambar 1. Ikan terbang atau torani atau bony flying fish (Hirundichthys oxycepalus) di perairan barat Papua.

Sumber: Fish Base, FAO 


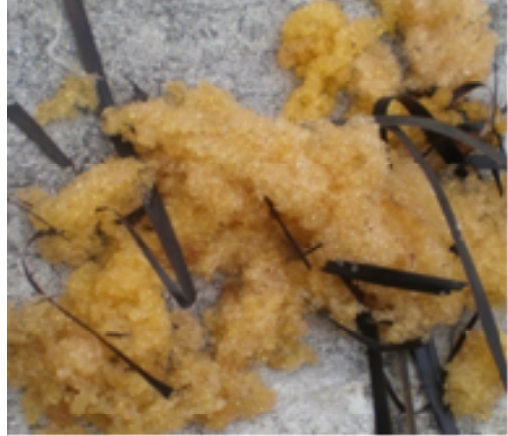

a

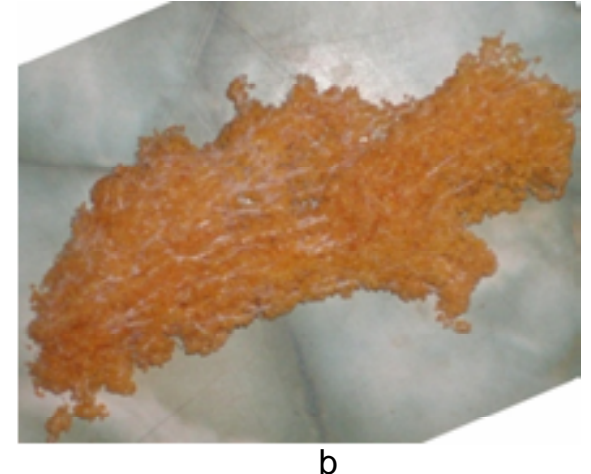

b

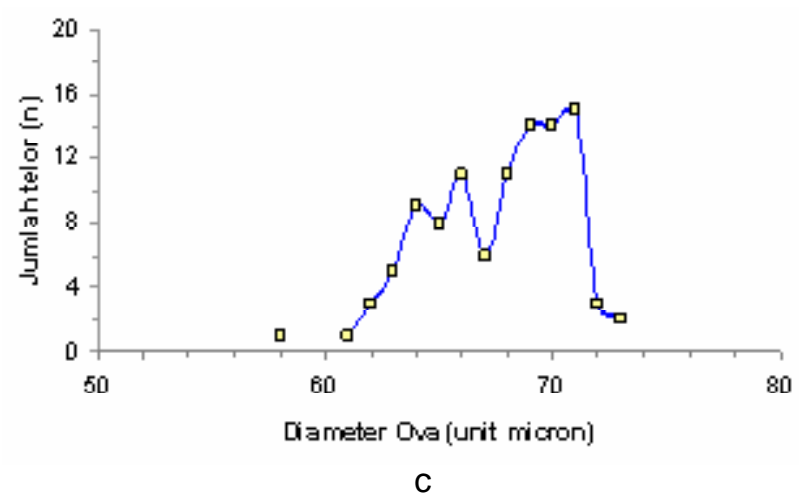

Gambar 2. Contoh telur ikan terbang (H. oxycephalus) yang diupayakan nelayan di perairan sekitar FakFak: a. telur segar; b. telur telah dijemur 2-3 hari; c. sebaran diameter telur atau ova segar.

mengangkat jaring hiu (Shark) ditemukan banyak sekali telur ikan terbang menempel pada jaring; selain itu di sekitar perahu juga terlihat banyak gerombolan induk ikan terbang. Sebagai nelayan Selat Makassar yang berpengalaman dalam penangkapan ikan terbang (beserta telur) di daerah (Selat Makassar dan Laut Flores), maka dicoba penangkapan untuk mendapatkan telur ikan lebih banyak, apalagi diketahui bahwa hasil tangkapan telur ikan terbang di daerah semakin menurun akibat eksploitasi yang terus-menerus. Hasil ternyata sangat baik, diperoleh tangkapan telur ikan terbang sebanyak 3 ton, kemudian dibawa ke Selat Makassar. Produksi yang tercatat waktu itu (tahun 2001) adalah $2.270 \mathrm{~kg}$.

Dari pengalaman tersebut pada tahun berikutnya (tahun 2002) datang sekitar 170-an kapal pakaja dari Selat Makassar untuk mengupayakan telur ikan terbang. Hasil tangkapan yang tercatat oleh Dinas Kelautan dan Perikanan Kabupaten Fak-Fak tahun 2002 adalah 33.472 kg, di Kaimana tercatat 370 kg. Hampir sebagian besar nelayan ikan terbang berasal dari Selat Makassar, dan hanya sebagian kecil nelayan yang berasal dari Fak-Fak dan Mandar (Sulawesi Barat) yang mencoba menangkap telur ikan terbang di daerah ini.

\section{Peningkatan Upaya dan Total Hasil Tangkapan}

Peningkatan upaya penangkapan (jumlah kapal) telur ikan terbang oleh nelayan Selat Makassar nyata sekali terlihat sejak tahun 2001, yaitu dari sekitar 171 kapal pada tahun 2002 menjadi 558 kapal pada tahun 2006 dan 915 kapal pada tahun 2007 (Gambar 3a) data ini diperoleh sampai bulan Juli 2007. Selanjutnya, jumlah kapal pakaja yang terdaftar diperoleh berdasarkan pada surat izin penangkapan ikan yang diterbitkan Dinas Perikanan dan Kelautan Kabupaten Fak-Fak hampir seluruh nelayan berasal dari Galesong atau Takalar (Selat Makassar).

Sejalan dengan peningkatan jumlah kapal yang terdaftar tersebut, trend kenaikan produksi telur ikan terbang terus terjadi selama periode tahun 2001Agustus 2007, yaitu dari 2,5 ton pada tahun 2001 menjadi sekitar 69 ton pada tahun 2005, 60 ton pada tahun 2006, dan 94 ton pada tahun 2007. Dengan demikian, rata-rata produksinya adalah 42 ton/tahun. Perlu dicatat bahwa produksi telur tersebut produksi yang dikatakan melalui registrasi pengiriman komoditi ke luar daerah. kemungkinan besar terdapat selisih produksi telur ikan terbang yang tercatat (dikirimkan) dengan produksi riil yang menurut salah seorang 
juragan pengumpul dapat mencapai $100 \%$. Sebagai pembanding pada tahun-tahun terakhir perkembangan (antara tahun 1999-2001), produksi telur ikan terbang di Sulawesi Selatan sekitar 200 ton (Syahailatua, 2006). Anjlognya produksi telur pada tahun 2003 dikarenakan kondisi pasar yang tidak menguntungkan. Walaupun sumber daya ikan terbang bersifat sumber daya dapat pulih (renewable resources), trendkenaikan produksi telur yang seiring dengan peningkatan upayanya ini diduga belum menjamin hasil tangkapan yang menguntungkan dengan ketersediaan sumber daya yang tetap terjamin dalam jangka panjang (tindakan pengelolaan yang bertanggungjawab; Martosubroto, 2005). Hal ini terkait dengan aspek operasional penangkapan, biaya eksploitasi, dinamika perikanan, dan keragaan hasil tangkapan sendiri. Diperlukan studi lebih lanjut tentang hal-hal tersebut untuk dapat memberikan opsi kebijakan yang logis dan akurat sesuai kebutuhan (pengelolaan yang bertanggungjawab).

\section{Fluktuasi Musiman dan Keragaan Hasil Tangkapan}

Fluktuasi hasil tangkapan secara musiman (Gambar 3b) memperlihatkan bahwa setiap tahun (tahun 200-2007) musim penangkapan telur ikan terbang berlangsung selama lima bulan, yaitu dari bulan Mei sampai dengan September; dengan puncaknya antara bulan Juli sampai Agustus. Musim telur ikan terbang yang tetap (bulan Mei-September) dan juga pola musiman tersebut sangat jelas menggambarkan musim pemijahan ikan terbang di perairan ini yang diyakini berlangsung pada bulanbulan tersebut, karena telur yang dipanen adalah telur yang telah dipijahkan dan menempel di daun kelapa (rumpon) yang digunakan oleh nelayan. Dari studi reproduksi (nisbah kelamin, komposisi visual kematangan gonad, fluktuasi indeks kematangan gonad, dan pengamatan mikroskopis terhadap telur atau ova) yang dilakukan di perairan Selat Makassar dan Laut Flores, ikan terbang sudah mulai memijah pada bulan Pebruari-Maret, puncak pemijahan pada bulan Juni-Juli (musim timur) dan berakhir pada bulan September-Oktober (Ali \& Nessa, 2006). Selanjutnya, ikan terbang memiliki tipe pemijahan parsial, yaitu dalam 1 musim pemijahan ikan terbang memijah lebih dari 1 kali (diduga 3-4 kali), sedang di perairan Tual, musim pemijahan yang hampir sama ditunjukkan dari hasil pengambilan contoh pada bulan Agustus 1994 terhadap jenis Cypselurus oligolepis dan C. spilopterus yang memperlihatkan sebagian besar gonad dari kedua jenis (masing-masing 83 dan $75 \%$ ) dalam kondisi aktif reproduktif (tingkat matang atau ripe dan salin atau spent) (Syam et al., 2004). Dengan

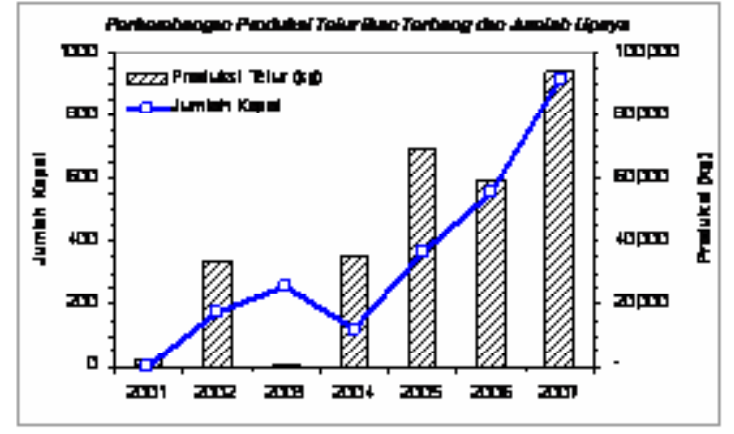

a

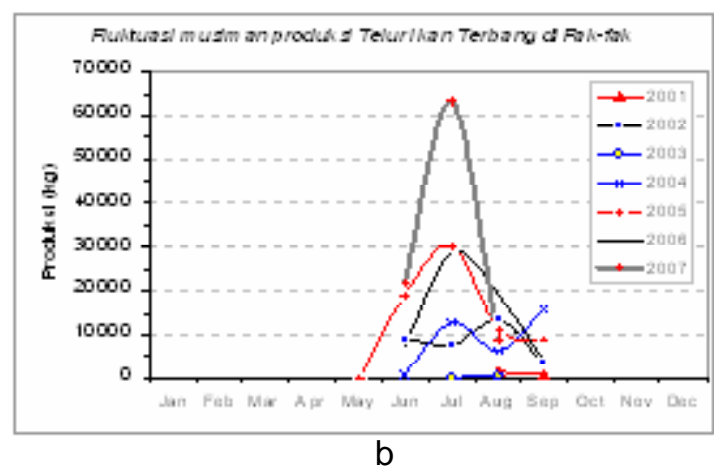

$\mathrm{b}$

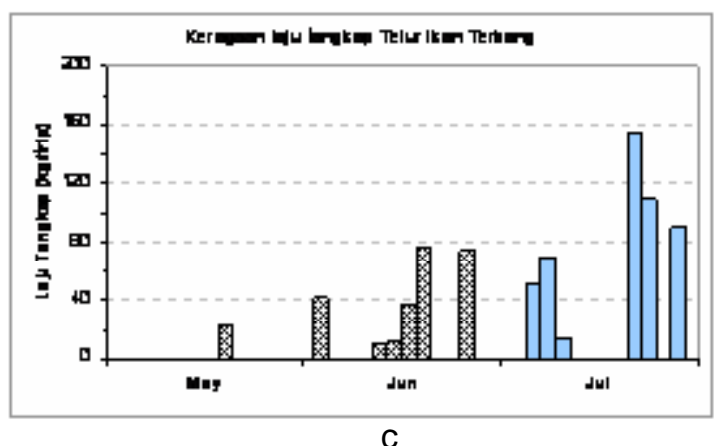

Gambar 3. Kondisi eksploitasi telur ikan terbang (H. oxycephalus) di perairan sekitar Fak-Fak (Papua Barat) tahun 2001 sampai 2007; a. trend kenaikan produksi dan upaya (jumlah kapal); b. fluktuasi musiman hasil tangkapan telur; c. sebaran laju tangkap telur (kg per trip) bulan Mei -Juli 2007. 
demikian, perlu dilakukan studi biologi reproduksi dan dinamika populasi ikan terbang di perairan sekitar Fak-Fak secara seksama untuk mendapatkan parameter-parameter dan indikator biologi yang dapat digunakan sebagai dasar pengelolaan.

Dari data monitoring hasil tangkapan oleh enumerator terhadap sejumlah nelayan (20 nelayan) selama bulan Mei-Juli 2007 yang tersedia, hasil tangkapan telur ikan terbang bervariasi antara 10-500 kg/trip/kapal; laju tangkap (kg/trip/kapal) sejak bulan Mei, Juni, dan Juli 2007 menunjukkan semakin tinggi, masing-masing 23, 46, dan $110 \mathrm{~kg} /$ trip. Sebaran nilai laju tangkap telur ikan terbang (kg/trip) dipresentasikan pada Gambar 3c. Selain itu, pada bulan Juli 2007 juga tercatat 7 kapal dengan hari operasi sekitar satu minggu dan diperoleh hasil 900 kg. Sebagai indeks kelimpahan, nilai-nilai laju tangkap telur ikan tersebut mempertegas pola musiman pemijahan.

Di Selat Makassar dan Laut Flores, musim penangkapan ikan terbang berlangsung antara bulan Januari-Oktober, sedangkan musim induk ikan (dewasa mature) antara bulan Maret-Juli, dan musim penangkapan telur antara bulan Mei -September (Ali dalam Ali \& Nessa, 2006).

Operasional penangkapan telur oleh nelayan memerlukan jumlah hari di laut yang bervariasi, tercatat antara 1 minggu-2 bulan, umumnya sekitar 1 bulan. Meskipun data upaya (dalam jumlah hari di laut) belum cukup tersedia, dapat diduga bahwa eksploitasi ini cenderung tak terkontrol mengingat belum tersedia aturan-aturan penangkapan yang memenuhi berbagai kaidah (ekonomi, sumber daya, dan lingkungan).

\section{TAKTIK DAN STRATEGI PENANGKAPAN}

Berbeda dengan sistem penangkapan di perairan Selat Makassar sampai Laut Flores yang menggunakan jaring insang ( gill net) yang efektif untuk menangkap ikan terbang dan bubu hanyut (rumpon) yang diberi daun kelapa untuk menarik ikan terbang meletakan telur (Tambunan, 2006), sasaran penangkapan nelayan ikan terbang di perairan sekitar Fak-Fak hanya ditujukan bagi telur, yaitu dengan menggunakan rumpon daun kelapa.

\section{Kapal Penangkap dan Rumpon Daun Kelapa untuk Menangkap Telur}

Kapal yang digunakan adalah kapal-kapal pakaja yang datang khusus dari Selat Makassar yang digunakan untuk mengupayakan ikan terbang beserta telurnya di Selat Makassar dan Laut Flores. Kapal berukuran 10-15 GT dengan panjang 14 m, lebar 22,5 m, dan dalam 0,8-1,0 m (Gambar 4a dan c). Anak buah kapal berjumlah 4- 6 orang. Kapal-kapal tersebut datang dari Selat Makassar sejak bulan April Agustus. Bulan April 2007 tercatat 130 kapal, disusul bulan Mei 2007721 kapal, dan bulan Juni-Juli 64 kapal. Aktivitas penangkapan dimulai pada bulan Mei 2007, sesuai dengan musim bertelur ikan terbang. Untuk mendatangkan kapal penangkap dari Selat Makassar menuju Fak-Fak memerlukan biaya sekitar Rp.25 juta per kapal; sedangkan biaya eksploitasi sekitar Rp.45 juta per trip. Karena mahalnya biaya transportasi dari Selat Makassar ke Fak-Fak, sebagian nelayan menempuh untuk meninggalkan kapal di Fak-Fak dan akan digunakan lagi pada musim tangkapan tahun yang akan datang.

Penangkapan telur dilakukan dengan alat bantu rumpon seperti yang dikembangkan di Selat Makassar dan Laut Flores. Rumpon terbuat dari daun kelapa yang dirangkai dengan bambu menjadi bentuk persegi bersisi kira-kira $1 \mathrm{~m}$ (Gambar 4b) untuk menarik ikan meletakan telur. Dalam pengoperasiannya rumpon dipasang secara vertikal di permukaan air. Pada setiap kali operasi penangkapan jumlah rumpon yang adalah antara 1050 buah. Dapat dibayangkan berapa banyak rumpon tersebar di daerah penangkapan telur ini. Rumpon daun kelapa merupakan pengembangan dari model alat tangkap telur sebelumnya (bubu hanyut) yang hanya dioperasikan di Selat Makassar dan Laut Flores.

\section{Amankah Penangkapan Telur Ikan Terbang di Papua dengan Menggunakan Rumpon Daun Kelapa?}

Pada musim pemijahan (musim ikan bertelur), induk ikan (stok pemijah atau spawning stock) terkonsentrasi di daerah pemijahan (spawning area) dan akan tertarik dengan benda-benda terapung sebagai tempat bertelur. Tingkah laku seperti ini dimanfaatkan oleh nelayan untuk mengumpulkan telur dengan meletakan rumpon daun kelapa sehingga akan menarik induk ikan bertelur. Dengan demikian, meskipun induk ikan (ikan dewasa dalam kondisi matang gonad) tidak ditangkap, tetapi alat ini mutlak akan mengumpulkan seluruh telur yang dipijahkan, tanpa kecuali, karena daun kelapa memiliki kapasitas yang besar untuk menarik induk ikan bertelur atau berpijah di situ (Ali \& Nessa, 2006) sehingga kemampuan mengoleksi telur yang dipijahkannya juga besar. Hal ini akan menyebabkan terputus siklus hidup yang akan menurunkan rekruitmen dan selanjutnya akan terjadi penurunan populasi (stok) dalam waktu cepat. Oleh karena itu, belajar dari pengalaman 

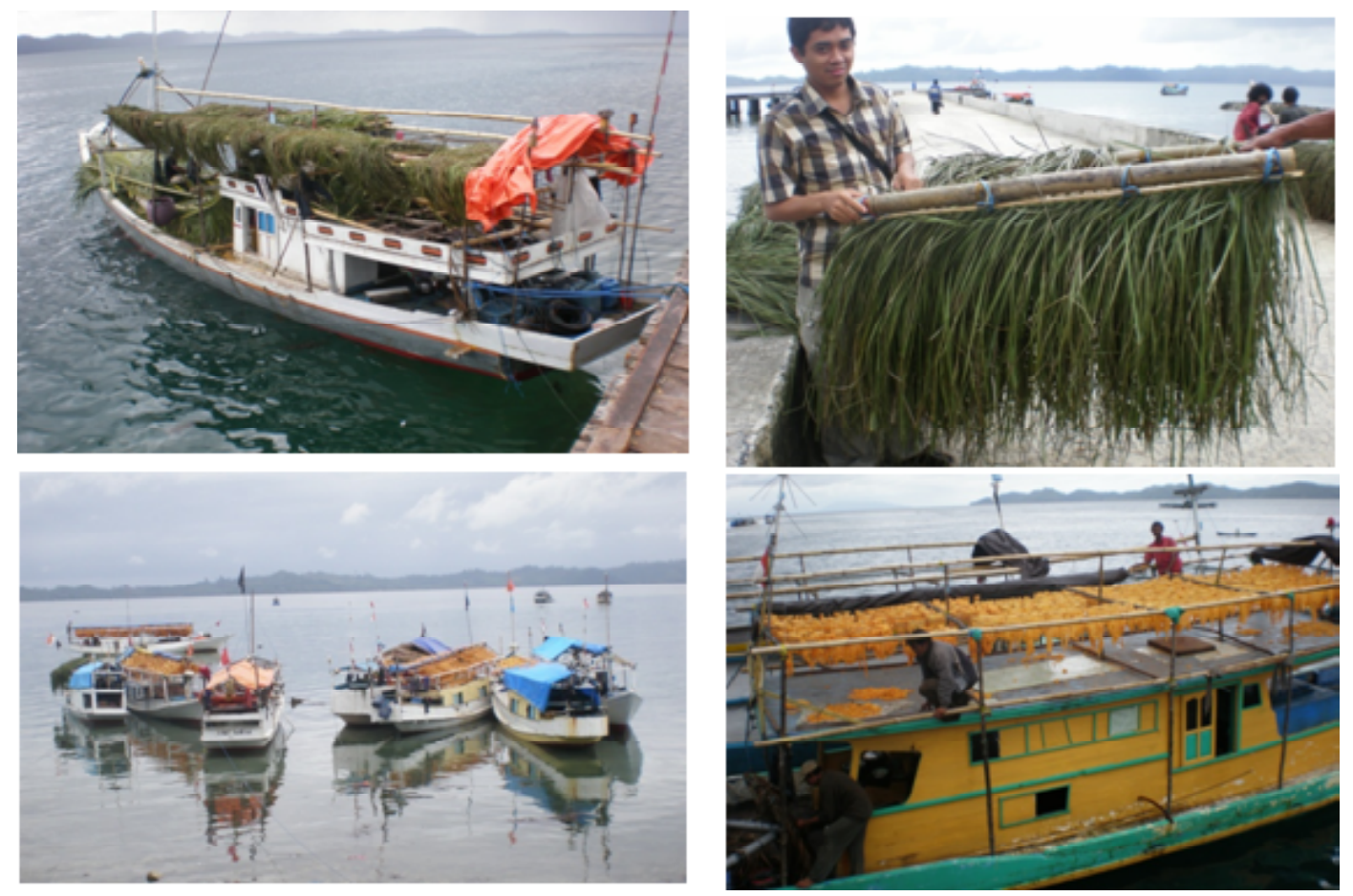

Gambar 4. Kapal-kapal pakaja asal Selat Makassar penangkap telur ikan terbang (Hirundichthys oxycephalus) di perairan sebelah barat Fak-Fak (Papua Barat): a. kapal dengan rumpon siap ke laut; b. seorang peneliti dengan contoh rumpon daun kelapa untuk menarik ikan terbang (Hirundichthys oxycephalus) betelur; c. armada penangkap pulang dari laut; dan d. hasil tangkapan telur dijemur di kapal.

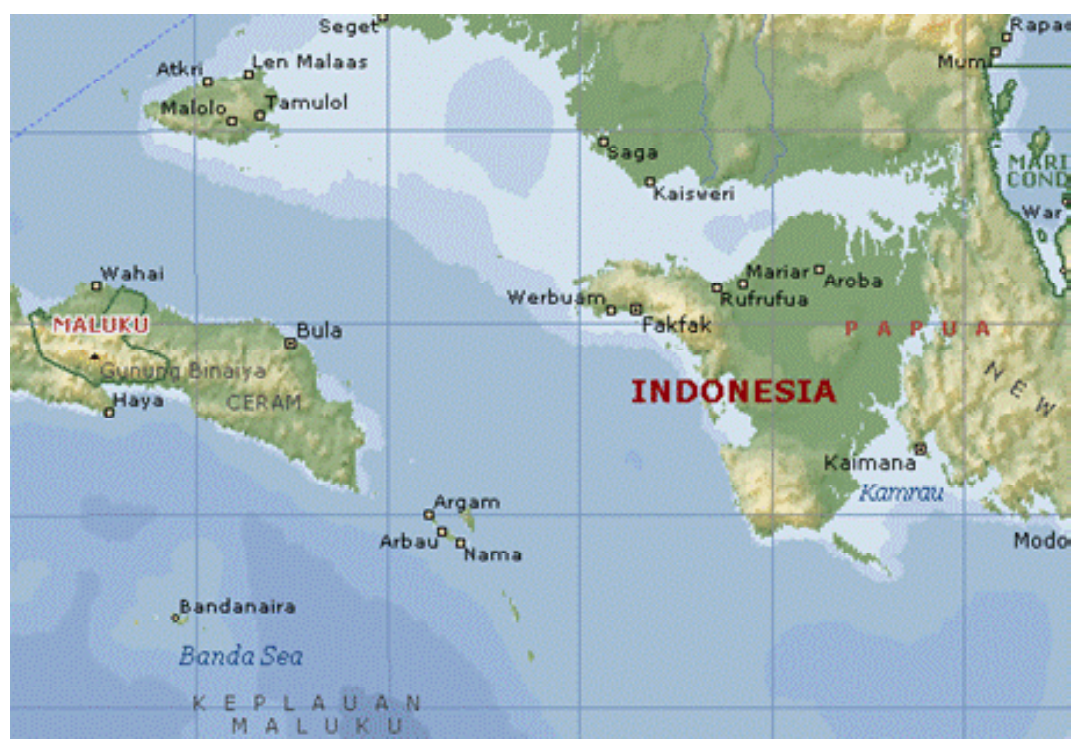

Gambar 5. Daerah penangkapan telur ikan terbang (Hirundichthys oxycephalus) di perairan sebelah barat Fak-Fak (Papua Barat).

perikanan ikan terbang di Selat Makassar dan Laut Flores, fenomena penggunaan rumpon daun kelapa sebagai alat tangkap telur dimungkinkan sangat mengganggu rekruitment dan kelestarian sumber daya.
Meskipun di Papua induk ikan tidak ditangkap, tetapi untuk sementara diduga sebagaimana ikan-ikan pelagis kecil perenang cepat pada umumnya, ikan terbang berumur pendek hanya 1 tahun lebih atau kurang dari 2 tahun sebagaimana dikatakan Campana 
et al. (1993), serta diperkirakan mengalami kematian paska pemijahan (post spawning mortality) seperti dikatakan Khokkiattiwong et al. (2000), sehingga induk ikan yang telah memijah kemungkinan tidak akan memijah lagi pada tahun yang akan datang. Terkait hal tersebut, Ali (2005 dalam Ali \& Nessa, 2006) mengatakan bahwa populasi ikan yang tertangkap pada musim pemijahan berukuran kecil dan homogen (1 cohort), tidak ditemukan ikan terbang dengan ukuran lebih besar atau tua (cohort lain).

\section{Daerah Penangkapan Telur dan Aspek Operasional}

Daerah penangkapan telur ikan terbang di perairan oseanik (laut dalam) di sebelah barat daya Fak-Fak sampai dengan perairan sebelah timur Seram, dapat ditempuh sekitar 1 jam dari daratan. Lokasi penangkapan ini tersebar ke arah tenggara sampai perairan sebelah utara Kaimana (Gambar 5). Lama operasi di laut bervariasi antara 7-64 hari, tetapi ratarata hari laut pada bulan Juni 2007 (24 hari) lebih rendah dibanding Juli (30 hari). Jumlah hari di laut dalam mengusahakan telur ini nampak akan semakin lama pada puncak musim telur atau dekat dengan puncak pemijahan. Hal ini pada umumnya sesuai perilaku nelayan yang ingin menangkap sumber daya sebanyak-banyaknya tanpa memperhatikan efisiensi dan kapasitas sumber daya. Selama beroperasi di laut ini, telur-telur yang diperoleh langsung di jemur di kapal dan dibawa ke darat dalam bentuk setengah kering. Di darat, telur-telur tersebut dijemur lagi, dan dibersihkan dari kotoran yang menempel. Penyusutan bobot dari telur segar atau basah menjadi telur siap kirim kira-kira 40-50\%.

\section{KESIMPULAN DAN SARAN}

\section{Kesimpulan}

1. Eksploitasi telur ikan terbang (Hirundichthys oxycephalus, famili Exocoetidae) dilakukan oleh nelayan dari Selat Makassar mulai berkembang efektif tahun 2002. Trend kenaikan produksi terus terjadi selama periode tahun 2001-2007, seiring dengan peningkatan upayanya (jumlah kapal penangkap aktif). Jumlah kapal aktif yang terdaftar selama bulan April- Agustus 2007 adalah 915 unit kapal.

2. Musim penangkapan telur berlangsung selama 5 bulan (bulan Mei-September), dengan puncaknya antara bulan Juli-Agustus. Periode tersebut dapat dikatakan merupakan musim pemijahan jenis tersebut. Dalam tahun 2007 (bulan Mei sampai Juli) laju tangkapan telur berkisar antara 10-500 kg/trip. Rata-rata laju tangkap menunjukkan adanya kenaikan selama 3 bulan ini, masing-masing 23, 46, dan $110 \mathrm{~kg}$ per trip; memperlihatkan modus pemijahan. Jumlah hari operasi penangkapan di laut antara 1 minggu-2 bulan, umumnya sekitar 1 bulan.

3. Beberapa aspek operasional penangkapan seperti peningkatan upaya atau effort (jumlah kapal penangkap, jumlah hari di laut, dan jumlah rumpon daun kelapa), hasil tangkapan per unit upaya (catch per unit of effort) dan lost production yang belum jelas diperkirakan nanti akan terlibat langsung dengan pengelolaan perikanan telur ikan terbang di daerah ini (pengelolaan perikanan yang bertanggungjawab dalam konteks keuntungan ekonomi). Selain itu, karakteristik biologi spesies (ikan terbang) yang belum diketahui ini (meliputi umur dan pertumbuhan, biologi reproduksi, pola diet, dan struktur genetik populasi), juga akan menjadi masukan penting guna penentuan kebijakan pengelolaan. Kajian stok untuk menaksir jumlah sediaan (stok atau biomassa) beserta kapasitas juga krusial untuk keperluan pengelolaan dan pengembangan.

\section{Saran}

Dari uraian di atas, kajian lebih lanjut terutama ditujukan untuk mendapatkan parameter dan indikator yang akan berguna sebagai bahan masukan bagi pengelolaan perikanan yang bertanggungjawab, antara lain menyangkut aspek-aspek sebagai berikut:

1. Observasi dan monitoring mengenai perkembangan jumlah kapal penangkap, identifikasi rumpon (jumlah dan distribusi di laut), jumlah hari laut, hasil tangkapan per unit upaya dan lost production.

2. Survei akustik dan oseanografi untuk menduga jumlah biomassa (stok ikan) dan ekologi ikan terbang (Hirundichthys oxycephalus) di perairan ini.

3. Studi life history ikan terbang seperti: umur dan pertumbuhan, biologi reproduksi, dan feeding habit.

4. Studi distribusi, kelimpahan, dan struktur genetik populasi ikan terbang, terutama di perairan-perairan wilayah Indonesia Timur yang menjadi habitat spesies ini, antara lain perairan barat Papua, sekitar Tual, Laut Banda, Laut Flores, dan Selat Makassar. 


\section{PERSANTUNAN}

Kegiatan dari hasil riset stok sumber daya ikan dan lingkungan di perairan Laut Arafura, T.A. 20062007, di Balai Riset Perikanan Laut-Muara Baru, Jakarta.

\section{DAFTAR PUSTAKA}

Ali, S. A. 1981. Kebiasaan makanan, pemijahan, hubungan panjang bobot, dan faktor kondisi ikan terbang, Cypselurus oxycephalus (Bleeker) di Laut Flores, Sulawesi Selatan. Tesis Sarjana Perikanan. Fakultas IImu-IImu Pertanian Universitas Hasanuddin. Ujung Pandang. 45 pp.

Ali, S. A. \& M. N. Nessa. 2006. Status ilmu pengetahuan ikan terbang di Indonesia (Hirundichthys oxycephalus). In S. B. A. Omar, M. N. Nessa, A. Syahailatua, S. A. Ali, I. Burhanuddin, A. Djamali, \& M. Hutomo (Eds.). Prosiding Loka Karya Nasional Perikanan Ikan Terbang Selat Makassar. 20-21 September 2005. Universitas Hasanuddin. Direktorat Jenderal Perikanan Tangkap. Departemen Kelautan dan Perikanan-Lembaga Oseanologi Nasional. Lembaga IImu Pengetahuan Indonesia. 16-37.

Anonimous. 1993. Daftar Biota Air Langka di Indonesia. Direktorat Jenderal Perikanan. Departemen Pertanian.

Campana, S. E., H. A. Oxenford, \& J. N. Smith. 1993. Radiochemical determination of longevity in flyingfish Hirundichthys affinis using TH-228/Ra228. Marine Ecology Prog. Ser. 100. 211-219.

Dalzell, P. 1993. The fisheries biology of flying fishes (families: Exocoetidae and Hemiramphidae) from the Camotes Sea, Central Philippines. Journal of Fisheries Biology. 43. 19-32.

Hutomo, M., Burhanuddin, \& S. Martosewojo. 1985. Sumber Daya Ikan Terbang. Seri: Sumber Daya Alam. 118. Lembaga Oseanologi Nasional. Lembaga IImu Pengetahuan Indonesia. 73 pp.

Khokkiattiwong, S. R. Mahon, \& W. Hunta. 2000. Seasonal abundance and reproduction of the four wing flying fish, Hirundichthys affinis of Barbados. Environmental Biology of Fishes. 59. 43-60.
Martosubroto, P. 2005. Menuju pengelolaan perikanan yang bertanggungjawab. Forum Pengkajian Stok Ikan Laut. Hotel Bintang. Jakarta. 27-28 Desember 2005.

Nessa, M. N., H. Sugondo, I. Andarias, \& A. Rantetondok. 1977. Studi pendahuluan terhadap ikan terbang di Selat Makassar. Lontara. 13: 643669.

Parin, N.V. 1999. Exocoetidae (Flyingfishes). In K. E. Carpenter \& V. H. Niem (eds.), FAO Species Identification Guide for fishery purposes the living marine resources of theWestern Central Pasific, Vol. 4. Bony Fishes Part 2 (Mugillidae to carangidae). Food and Agriculture Organization of the United Nations. Rome. 2.162-2.179.

Tambunan, P. 2006. Potensi dan kondisi perikanan ikan terbang di beberapa wilayah Indonesia. In S.B.A. Omar, M.N. Nessa, A. Syahailatua, S.A. Ali, I. Burhanuddin, A. Djamali, \& M. Hutomo (Eds.). Prosiding Loka Karya Nasional Perikanan Ikan Terbang. Makassar. 20-21 September 2005. Universitas Hasanuddin. Direktorat Jenderal Perikanan Tangkap. Departemen Kelautan dan Perikanan-Lembaga Oseanologi Nasional. Lembaga IImu Pengetahuan Indonesia. 9-15.

Peranginangin, R. 2006. Teknologi pengolahan telur ikan terbang. In S. B. A. Omar, M. N. Nessa, A. Syahailatua, S. A. Ali, I. Burhanuddin, A. Djamali, \& M. Hutomo (Eds.). Prosiding Loka Karya Nasional Perikanan Ikan Terbang. Makassar. 2021 September 2005. Universitas Hasanuddin. Direktorat Jenderal Perikanan Tangkap. Departemen Kelautan dan Perikanan-Lembaga Oseanologi Nasional. Lembaga IImu Pengetahuan Indonesia. 49-61.

Syahailatua, A. 2006. Perikanan ikan terbang di Indonesia: Riset menuju pengelolaan. Oseana. 31. (3). 21-31.

Syahailatua, A. M. Hutomo, \& A. Djamali. 2006. Strategi penelitian ikan terbang di Indonesia sampai dengan tahun 2010. In S. B. A. Omar, M. N. Nessa, A. Syahailatua, S. A. Ali, I. Burhanuddin, A. Djamali, \& M. Hutomo (Eds.). Prosiding Loka Karya Nasional Perikanan Ikan Terbang. 
Makassar. 20-21 September 2005. Universitas Hasanuddin. Direktorat Jenderal Perikanan Tangkap. Departemen Kelautan dan PerikananLembaga Oseanologi Nasional. Lembaga IImu Pengetahuan Indonesia. 62-71.

Syam, A. R., T. Zubaidi, \& I. N. Edrus. 2004. Aspek biologi reproduksi ikan terbang Cypsilurus oligolepis dan Cypsilurus spilopterus di perairan Tual, Maluku Tenggara. Jurnal Penelitian Perikanan Indonesia Edisi Sumber Daya dan Penangkapan. 10 (4). 87-95.
Weber, M. \& de Beaufort. 1992. The fishes of the Indo-Australian archipelago. E. J. Brill. Leiden. 4. $410 \mathrm{pp}$. 